\title{
An Examination of the Key Drivers of Amendments to the Standard Forms of Contract in the South African Construction Industry
}

\author{
"Modupe Cecilia Mewomo', Clinton Aigbavboa² and Portia Lesalane²
}

Published online: 31 August 2018

To cite this article: Modupe Cecilia Mewomo, Clinton Aigbavboa and Portia Lesalane (2018). An examination of the key drivers of amendments to the standard forms of contract in the South African construction industry. Journal of Construction in Developing Countries, 23(1): 115-124. https://doi.org/10.21315/jcdc2018.23.1.7.

To link to this article: https://doi.org/10.21315/jcdc2018.23.1.7

\begin{abstract}
Some of the perceived benefits of standard forms of contract are standardisation, uniformity, stability and the availability of well-established terms and conditions which allow predictability and greater certainty in legal relations. Thus, the standard forms are widely adopted in the construction industry to facilitate the contractual arrangements between contracting parties in a construction project. Having become commonplace in construction transactions, they are often generally accepted by the various contracting parties and their advisers. Notwithstanding its importance, literature suggests that it is practically unfeasible to devise a standard form of contract that would cater for all eventualities and construction issues that might occur in construction projects. As a result, the existing standard forms are sometimes amended or modified in order to fit the clients' requirements and also to suit the contractors' expectations. This paper therefore investigates the key factors that drive amendments to the standard forms of contract in the South African construction industry. Considering the fact that this paper presents findings that relied on a descriptive survey method, the mean item score was used for presenting the results. The data was obtained through an online questionnaire survey sent to the construction professionals who are usually involved in the selection of contract forms for the client in the Gauteng Province of South Africa (SA). The data was analysed using the statistical package for the social sciences (SPSS) and the results indicate that "altering risk allocation", "inserting additional obligation" and "correcting something which is not applicable" are the three prominent factors that highly drive the amendment of standard forms of contract in the Gauteng Province of South Africa.
\end{abstract}

Keywords: Amendments, Contracting, Drivers, South Africa, Standard forms of contract

\section{INTRODUCTION}

The construction process is complex and it involves diverse risks. These risks come in different forms and may be connected with design, construction operation or external factors. The diversity of risks and complexity of construction process, as well as the administrative procedures required in construction projects have all driven the industry perception that the use of standard forms of contract tends to minimise avoidable transaction costs and leads to greater efficiency in procurement overall (Sharkey et al., 2014; Intercontinental Exchange [ICE], 2017). Consequently, the standard forms of contract conditions are developed to provide mechanisms that can deal with the situations that may arise during the course of

\footnotetext{
'Department of Construction Management and Quantity Surveying, Durban University of Technology, SOUTH AFRICA

${ }^{2}$ Department of Construction Management and Quantity Surveying, University of Johannesburg, SOUTH AFRICA

"Corresponding author: modupem@dut.ac.za
}

(C) Penerbit Universiti Sains Malaysia, 2018. This work is licensed under the terms of the Creative Commons Attribution (CC BY) (http://creativecommons.org/licenses/by/4.0/). 
construction projects (Ramus, Birchall and Griffiths, 2006). One significant feature of the standard condition of contract is that it contains ready-made terms and conditions that can easily be used in the execution of construction projects (South African Council for the Quantity Surveying Professions [SACQSP], 2014). Thus, it has become commonplace in construction transactions and is generally accepted by the different contracting parties. Literature is replete with the benefits associated with the use of the standard form of construction contracts. Some notable ones include standardisation, uniformity, stability and the availability of well-established terms and conditions which allow predictability and greater certainty in legal relations between contracting parties (Construction Industry Development Board [CIDB], 2005; Richards et al., 2005; Cunningham, 2013; Kanamugire, 2013; ICE, 2017). The SACQSP (2014) has noted the importance of standard forms of contract in facilitating the contractual arrangements between parties in a construction project. Furthermore, a report by ICE (2017) revealed that standard forms of contract help to minimise the time and costs associated with negotiating contracts. As such, there is strong support for the use of standard forms of contract across the globe (Sharkey et al., 2014).

Notwithstanding the importance of these forms, past studies have established the fact that it is practically impossible for a standard form of contract to allow for all the varying specifics of every individual project. The studies of Ndekugri and Rycroft (2009), the SACQSP (2014) and Sharkey et al. (2014) are testament to this allusion. The research report of the study conducted by Sharkey et al. (2014) revealed that no forms of contract conditions could be considered as suitable to be used in the Australian construction industry without significant amendments being made. Although the report by Sharkey et al. (2014) is specifically about the Australian construction industry, some other professionals have also established the fact that there are situations where some amendment is necessary owing to the diverse nature and unique characteristics of different projects (Ndekugri and Rycroft, 2009; Murdoch and Hughes, 2008; Cunningham, 2013). In the light of this background information, this paper investigates the factors that drive amendments to the standard forms of contract in the South African construction industry.

\section{THE IMPORTANCE OF STANDARD FORMS OF CONTRACT CONDITIONS IN CONSTRUCTION PROJECTS}

The standard forms of contract are considered an essential element of day-to-day commercial life (Kanamugire, 2013). From the literature in the field of construction, this fact has been severally and consistently confirmed (Othman, 2008; Richards et al., 2005; Cunningham, 2013). In construction, the standard forms are predominantly being used to provide a contractual basis on which construction transactions can be conducted. They contain established terms and conditions that arise from the extensive discussions and compromises between the clients' representatives, experts' bodies and the built environment professions (Cunnigham, 2013; Richards et al., 2008). Thus, the standard forms are perceived to be a fair and equitably balanced allocation of risks and power between the parties to construction contracts. Ramus, Birchall and Griffiths (2006: 52) earlier defined the standard forms of contract as "... a form that is developed to provide formal, predetermined arrangements and mechanisms to cope with the situations that can arise during the course of a construction project". They are specifically developed to offer a pragmatic 
approach to solving construction issues (Cunningham, 2013). In order to achieve its purpose, amendments to its contents should be kept to a minimum. ICE (2017) has noted the fact that complex interaction exists between many of the clauses within the standard forms. Therefore, any modification to the clauses should be carried out with care and by a specialist with good knowledge of construction and law of contracts. In addition, the person modifying any of the clauses must ensure that the wording are clear in order to avoid any uncertainty. Disputes usually occur when contracting parties have different interpretations for the modified clauses. Courts therefore rely on contra proferentem and reasonableness principles to deal with any ambiguous modified clauses (Furst et al., 2008). The principle of contra proferentem provides that, where a party modifies a clause it is their responsibility to make the wording clear and so they should lose out if there is ambiguity. Therefore, any amendment should be jointly agreed upon and extra care needs to be taken by employers and contractors both in drafting amendments and in considering full contractual implications on each party.

\section{Forms of Contract Available for South African Construction Industry}

In South Africa, there is a large array of standard forms of contract available for different construction and procurement type. However, the CIDB condemned the practice of having too many standard forms in the industry. The Board subsequently approved only four forms with the purpose of making procurement reform efficient within the SA construction industry (CIDB, 2005). The four CIDB accredited forms are the Joint Building Contracts Committee (JBCC), the General Condition of Contracts (GCC), the New Engineering Contracts (NEC3) and the International Federation of Consulting Engineers (commonly called FIDIC). According to the Board, the four endorsed standard forms collectively cover the frequently encountered contracting strategies that are presently being pursued in SA, both locally and internationally. The JBCC is restricted to building works, whereas the other three recommended forms can be used in all types of construction contracts and engineering projects. One significant advantage of these forms is that they promote standardisation and uniformity of documentation (CIDB, 2005). In addition, the availability of wellestablished terms and conditions within the forms allows stability, predictability and greater certainty in legal relations (SACQSP, 2014). Thus, the forms help in providing certainty regarding the nature of transactions between parties on a project specific basis (Masterman, 1997; Richards et al., 2005).

Continuous utilisation of the standard form allows the contracting parties to be more familiar with its terms and conditions, thereby enabling the parties to be aware of their rights and obligations under the contract (Cunningham, 2013). Familiarity further promotes both clarity in the event of disputes and ease of contract administration (Cunningham, 2013; Sharkey et al., 2014). Having being tried and tested, the standard forms enjoy wide industry recognition and acceptance. Thus, the continuous usage helps in prohibiting the cost of customisation and reduced negotiation time.

Notwithstanding the wide recognition of the importance of the standard form and its fairness in dealing with construction issues, there have been arguments that there are situations where amendments are necessary because of the perception that no single standard forms could allow for all the varying specifics of every individual project (Ndekurgi and Rycroft, 2009; ICE, 2017). For instance, an amendment maybe needed in a situation where certain clauses become obsolete 
or the industry shifts and requires the inclusion of new terms (ICE, 2017). Murdoch and Hughes (2008) have commented that the use of a single standard form of contract is unrealistic owing to the diverse nature and unique characteristics of each building project. Thus, modifications may be needed to realign the form with the constantly changing industry (ICE, 2017). In addition, amending a standard form provides an opportunity for realignment while the contracting parties still benefit from the generally accepted wording of the rest of the contract. However, owing to the possibility of unintended consequences that may arise from altering the standard form, several professionals have cautioned that amendments should be approached with care and reluctance (ICE, 2017; Murdoch and Hughes, 2008; Cunningham, 2013).

\section{RESEARCH METHODOLOGY}

A quantitative study was carried out to investigate the professionals' perceptions of the key drivers of amendments to the standard forms of contract in the South African (SA) construction industry. The study sample was randomly drawn from construction professionals in Gauteng Province of SA. The Gauteng Province was selected since it is the most populous province with the highest recorded number of construction activities. The targeted respondents were the construction professionals within Gauteng Province who are usually involved in the selection of standard forms of contract conditions for their clients. These respondents include quantity surveyors, construction managers, construction project managers, structural engineers, and architects who provide professional services relating to their field of expertise in a given project. Table 1 shows the demographic analysis of the respondents.

Table 1. Demographic Data of the Respondents

\begin{tabular}{lcc}
\hline & Frequency & Percentage (\%) \\
\hline Profession of the respondents & & \\
Engineers & 15 & 14.71 \\
Quantity surveyors & 41 & 40.20 \\
Construction/project managers & 33 & 32.25 \\
Architects & 11 & 10.78 \\
Others & 02 & 1.96 \\
Working experience & & \\
1-5 years & 63 & 61.76 \\
6-15 years & 23 & 22.54 \\
Above 16 years & 16 & 15.70 \\
Construction industry sector & & \\
Private & 34 & 33.33 \\
Public & 68 & 66.67 \\
Forms of contract previously used by respondents & \\
FIDIC & 53 & 51.96 \\
NEC3 & 64 & 62.75 \\
GCC 2010 & 21 & 20.59 \\
JBCC & 65 & 63.73 \\
\hline
\end{tabular}


The analysis revealed that the respondents have considerable experience within the construction industry and are involved in both the private and public construction sectors. They have also used different forms of contract conditions in project execution. The years of experience of the various respondents, their usage and knowledge of different forms of contract and their level of involvement in the selection process made their contributions of great value to the study. The set objectives were achieved using a questionnaire survey. The design of the questionnaire was based on the recognised factors from the review of related literature. In the questionnaire, eight factors were presented to the respondents for confirmation of their significance as a key driver of amendment. The questionnaire survey attracted 102 responses, forming the basis of the analysis for the study. There are two main sections within the questionnaires. The first part is the introductory section to establish the respondents' knowledge and usage of standard forms of contract in project execution while the second section deals with the ranking of the eight identified factors of possible amendment drivers. The respondents were requested to rank their perception of the factors on a five-point Likert scale comprising effective levels of "Strongly disagree" = 1, "Disagree" = 2, "Neutral" = 3, "Agree" = 4 and "Strongly agree" = 5. The mean score (MS) for each variable was established and ranked from highest to the lowest as shown in Table 2. Adopting the mean value approach to arrive at the mean score, an item with a higher mean item score was ranked as the highest, since it represents its dominance among other items ranked. The determination of the significance of each of the factors was based on adopting a hypothesised mean of 3.5, drawing from Sherif and Kaka (2003) and Ling (2002), cited in Ahadzie, Proverbs and Olomolaiye (2008). Consequently, based on the five-point Likert scale, a factor was deemed very critical if it has a mean item score of 3.5 and above.

\section{RESULTS AND DISCUSSION}

As earlier noted, the mean item score technique was adopted in this study. The ratings given by each of the respondents were calculated to arrive at a mean score for each of the listed factors. The mean scores were ranked from the highest to the lowest and were used to determine whether the respondents considered a specific factor to be a key driver of amendments. In order to provide a clearer picture of the agreement reached by the respondents, the mean ranking of each factor has been presented in tabular form as depicted in Table 2.

According to the findings, "altering risk allocation" ranked highest with a mean item score (MIS) of 4.34, "inserting additional obligations" ranked second highest with a MIS of 4.04 , followed by "correcting something that is not applicable to the contract" which ranked third highest with a MIS of 3.62. These three factors emerged as the most prominent factors that drive the amendment to contract forms in the Gauteng Province of SA. The analysis further revealed "standard form perceived to be poorly drafted" as the factor with the lowest MIS of 2.74. The fact that this factor has the lowest mean score which is also less than the hypothesised mean of 3.5 implies that the factor is not a key driver of amendments. Thus, it can be argued that the standard forms of contract are generally perceived by the professionals in the Gauteng Province to be well drafted and the manner in which they are drafted does not constitute a key driver of amendments. This finding suggests that there is a link between the manner at which the standard forms are 
developed and its acceptability by the various contracting parties. Two important consequences emerged from this link. Firstly, the standard forms are a product of the agreement reached among the experts' bodies representing the interest of the industry, the clients and the construction professionals. Consequently, there is general perception that the terms of the contract condition is fair to all the parties involve. Secondly, the fact that the terms and conditions of the standard forms are a product of an extensive dialogue and the agreement reached by all the representatives involved in its development, likewise suggests that the terms and condition are clear to all the parties involved. In the light of these, the perceptions by the respondents that the standard forms are well drafted may be construed to mean that it is both fairly and clearly drafted. This result reaffirmed the validity of the earlier survey conducted in the UK, where the standard form is perceived to be fair, well established and contains tried and tested terms and conditions which make it enjoy the courts' and industry's recognition (Latham, 1994; Cunningham, 2013; Ramus, Birchall and Griffiths, 2006).

Table 2. Key Drivers of Amendments to Standard Forms of Contract

\begin{tabular}{lcccc}
\hline \multicolumn{1}{c}{ Variables } & N & $\begin{array}{c}\text { Mean Item } \\
\text { Score }\end{array}$ & SD & Rank \\
\hline Altering risk allocation & 102 & 4.34 & 0.87 & 1 \\
Inserting additional obligation & 102 & 4.04 & 1.04 & 2 \\
$\begin{array}{l}\text { To correct something which is not applicable or } \\
\text { should not exist }\end{array}$ & 102 & 3.62 & 1.01 & 3 \\
$\begin{array}{l}\text { Increased ease of contract administration } \\
\text { Removing rights }\end{array}$ & 102 & 3.48 & 1.01 & 4 \\
To reflect regulatory requirements (e.g. residential & 102 & 3.27 & 1.19 & 5 \\
building legislation) & 102 & 3.23 & 1.01 & 6 \\
$\begin{array}{l}\text { Method of payment } \\
\text { Form perceived to be poorly drafted }\end{array}$ & 102 & 3.22 & 1.07 & 7 \\
\hline
\end{tabular}

A close look at the result shows that "altering risk allocation" is the most important key driver for making amendments to the standard forms of contract. This was similarly the case observed in Australia as reported by Sharkey et al. (2014). According to this report, $84 \%$ of the contract which employed a standard forms were amended from the relevant published form. In addition, the need to shift risk was identified as the main reason for amendment. In fact, a survey by the Royal Institute of Chartered Surveyors (RICS) as reported by Cartlidge (2013) also noted "altering risk allocation" and "inserting additional obligation" as some of the reasons for making amendments to the standard forms of contract. When delving more deeply into the findings, "correcting something that is not applicable to the contract" emerged as the third key driver of amendments. This finding reaffirmed the observation of Towey (2013), namely that standard forms of contract are written for general use yet can be modified for particular requirements, for instance, to correct something because it is not applicable or should not exist.

Generally, the complexity and uncertainty involved in the construction process make it prone to high levels of risk. As such, many clients or their advisers 
modify the standard forms to meet the demands of the varying nature and unique characteristics of their project. Whilst it is understandable that certain situations can make alteration to the terms and condition of standard forms inevitable, literature revealed that some clients and their representatives amend forms of contract with the purpose of shifting risk to the other parties (Latham, 1994; Cunningham, 2013). Many professionals have condemned this attitude. For instance, the Latham report (1994) specifically recommended the use of a standard form of contract without any amendments. He condemned alteration of any form to the standard on the basis of the observation that most consultants amend the form to remove areas of risk from their employers. Besides, several consequences are reported to be associated with modifying clauses in the standard form of contract. For example, some clauses are cross-referenced with others and any alteration to such clauses may render them inconsistent and thus unenforceable. Furthermore, the complex interactions among the clauses can engender misinterpretation, legal uncertainty and risk imbalances when the forms are revised (ICE, 2017; Ndekugri and Rycroft, 2009). Moreover, there is the possibility of a court interpreting ambiguous revisions as contra proferentem, which could eventually be to the disadvantage of the party altering the document (Cunningham, 2013). Thus, many professionals have warned against unnecessary alteration of the forms of contract, as the form would no longer be standard and its benefits would be reduced (Murdoch and Hughes, 2008; Latham, 1994; ICE, 2017). Whilst it is true that amendments may be needed in certain conditions, it is important to take care and amend the form only when it is in every way necessary and then an amendment must be done in such a way that it will not jeopardise the easy administration of construction activities.

\section{The Effects of Altering Standard Forms of Contract}

Many researchers have advised against the practice of altering the standard forms of contract because of the possible negative consequences that may arise from doing so. ICE (2017) noted the fact that some professionals are of the opinion that the standard forms should not be amended through choice because of the complex interaction that exist between many of the terms. One significant reason for this opinion is that modification can change the balance of risk and create legal uncertainty (ICE, 2017; Ndekurgi and Rycroft, 2009; Kanamugire, 2013). In fact, Latham (1994) strongly condemned the practice of making amendment and recommended the use of the standard form without any alteration. The observation of these professionals is that the standard form of contract becomes something less than standard whenever an alteration/amendment is made and this may result in the standard form losing its value (ICE, 2017). Whilst some professionals have argued that no standard form of contract could allow for all the varying specifics of every individual project, amendment are expected to be approached with reluctance and caution (Ndekurgi and Rycroft, 2009). Literature reveals that the consequences and impacts of modifying the standard forms of contract are very great. Firstly, amendments can disrupt the balance of risk and impact on the true purpose of the form in providing a fair contractual framework that can enable a successful project (ICE, 2017). Secondly, many clauses are cross-referenced with others, alteration of one of such clauses can render it inconsistent with other related terms and as such create interpretation and enforcement problems. It is therefore important to consider the effects of alterations, consider whether amendments are necessary 
in the first instance and ensure that any of the terms amended does not have damaging effects on the other interrelated clauses.

\section{Re-allocation of Risk on Construction Projects}

A close observation of the findings from Table 2 also suggests that the two highest scoring factors are not mutually exclusive in that the parties may be adding/ deleting terms in order to re-allocate risks. Whilst it is true that no construction project is risk free, equitable allocation of risks among parties are very important (Peckiene, Komarovska and Ustinovicius, 2013). Risk cannot be ignored but can be managed, reduced, transferred or accepted (Lam et al., 2007). The general principle has been that risk should be allocated to the contracting party best able to handle it. However, the task of risk allocation among contracting parties is mostly carried out by the employers' thus resulting in improper and contractor-unfavourable risk allocation outcome (Peckiene, Komarovska and Ustinovicius 2013). Although, there has been an emphasis on the equitable and balanced risk allocation among contracting parties, Latham has claimed that the standard forms were often seriously amended by the consultants to remove areas of risk from their employers (Latham, 1994). This practice has not only resulted in cost and/or time overrun but has, in many instances, caused serious legal disputes (Peckiene, Komarovska and Ustinovicius, 2013). Thus, it is important to allocate risk under cooperative decision and put into consideration the capability of each party to handle a particular risk.

\section{CONCLUSION}

This paper has reported on the key drivers of making amendments to the standard forms of contract in the Gauteng Province of SA. Within this study, eight factors that can drive the amendment were examined. From the results obtained, "altering risk allocation", "inserting additional obligation" and "correcting something which is not applicable" ranked as the three key drivers of amendments. Delving more deeply into the results, it was revealed that "form perceived to be poorly drafted" has the lowest frequency. The implication of these results is that there is an indication of industry support for the fairness and usefulness of the standard forms of contract conditions in providing structures on which construction transactions can be conducted. However, certain situations can make alteration to some of its terms and condition inevitable, for instance, to correct something that is not applicable to a particular contract.

Whilst this report reflects the situation pertaining to the Gauteng Province of $\mathrm{SA}$, it also reflects similar situations in other countries as reported under the analysis and discussion of findings. Though amendments to forms of contract may be inevitable in some instances, in order to make them adaptable to the constantly changing industry, it is important to consider the implications of such amendments on contract execution and also to reason whether such amendments would have any damaging consequences on the smooth running of the entire contract. Thus, any choice modification should be thoroughly considered only when it is absolutely necessary and will not affect the construction process in any unintended way. 


\section{REFERENCES}

Ahadzie, D.K., Proverbs, D.G. and Olomolaiye, P. (2008). Critical success criteria for mass house building projects in developing countries. International Journal of Project Management, 26(6): 675-687. https://doi.org/10.1016/j. ijproman.2007.09.006.

Cartlidge, D. (2013). Quantity Surveyor's Pocketbook. 2nd Ed. Oxford: Elsevier.

Construction Industry Development Board (CIDB). (2005). Choosing an Appropriate Form of Contract for Engineering and Construction Works. Pretoria, South Africa: CIDB. Available at: www.cidb.org.za/documents/choosing-anapporopriate-form-of-contract-for-engineering-and-construction-works/ [Accessed on 13 February 2015].

Cunningham, T. (2013). Choosing an appropriate main contract for building work in the Republic of Ireland: An overview. Masters diss. Dublin Institute of Technology.

Furst, S., Ramsey, V., Williamson, A. and Uff, J. (2008). Keating on Construction Contracts: First Supplement to the Eighth Edition. London: Sweet and Maxwell.

Intercontinental Exchange (ICE). (2017). Modifying Clauses in Standard Forms of Construction Contract. Atlanta: ICE. Available at: https://www. designingbuildings.co.uk/wiki/Modifying_clauses_in_standard_forms_of_ construction_contract [Accessed on 22 February 2017].

Kamamugire, J.C. (2013). The future of standard forms contract in South Africa with particular reference to recent developments in law. Mediterranean Journal of Social Sciences, 4(13): 335-352.

Lam, K.C., Wang, D., Lee, P.T.K. and Tsang, Y.T. (2007). Modelling risk allocation decision in construction contracts. International Journal of Project Management, 25(5): 485-493. https://doi.org/10.1016/j.ijproman.2006.11.005.

Latham, M. (1994). Constructing the team. Final Report of the Government/Industry Review of the Procurement and Contractual Arrangements in the United Kingdom Construction Industry. London: Her Majesty's Stationery Office (HMSO).

Ling, Y.Y. (2003). A conceptual model for the selection of architects by project managers in Singapore. International Journal of Project Management, 21 (2): 135-144. https://doi.org/10.1016/S0263-7863(02)00014-5.

Masterman, J.W.E. (1997). An Introduction to Building Procurement Systems. New York: E \& FN Spon.

Murdoch, J.R. and Hughes, W. (2008). Construction Contracts: Law and Management. 4th Ed. Oxford: Taylor and Francis.

Ndekugri, I. and Rycroft, M. (2009). JCT 05 Standard Building Contract: Law and Administration. 2nd Ed. Oxford: Butterworth-Heinemann.

Othman, N. (2008). Standard forms of contract and its influence on construction professional. Jurnal Alam Bina, 11 (2): 45-60.

Peckiene, A., Komarovska, A. and Ustinovicius, L. (2013). Overview of risk allocation between construction parties. Procedia Engineering, 57: 889-894. https://doi. org/10.1016/j.proeng.2013.04.113.

Ramus, J., Birchall, S. and Griffiths, P. (2006). Contract Practice for Surveyors. 4th Ed. London: Butterworth Heinemann.

Richards, P., Bowen, P., Root, D. and Akintoye, A. (2005). Client strategic objectives: The impact of choice of construction contract on projects delivery. Construction Law Journal, 7: 21. 
Sharkey, J., Bell, M., Jocic, W. and Marginean, R. (2014). Standard Forms of Contract in the Australian Construction Industry. Melbourne: The University of Melbourne. Available at: http://law.unimelb.edu.au/_data/asseta/ pdf_file/0007/1686265/Research-Report-Standard-forms-of-contract-in-theAustralian-construction-industry.pdf [Accessed on 16 February 2016].

Sherif, E. and Kaka, A. (2003). Factors influencing the selection of payment systems in construction projects. Conference Proceedings of Association of Researchers in Construction Management. Brighton, England: University of Brighton, 63-70.

South African Council for the Quantity Surveying Professions (SACQSP). (2014). Professional Module No. 15: Understanding the Basic Principles of Construction Law in the Built Environment. Gauteng Province, South Africa:SACQS. Available at: http://c.ymcdn.com/sites/www.sacqsp.org.za/resource/collection/ A9A9E5E2-ECEF-4D7A-AA41-E2D754534E6D/Module_15_-_Construction_Law. pdf [Accessed on 15 February 2016]

Towey, D. (2013). Cost Management of Construction Projects. Chichester, UK: John Wiley and Sons. 